\title{
Polymorphisms of the ASIP gene and the haplotype are associated with fat deposition traits and fatty acid composition in Chinese Simmental steers
}

\author{
Yinuo Liu ${ }^{1}$, Xibi Fang ${ }^{1}$, Zhihui Zhao ${ }^{1,2}$, Junya Li $^{3}$, Elke Albrecht ${ }^{4}$, Lisa Schering ${ }^{4}$, Steffen Maak ${ }^{4}$, and \\ Runjun Yang ${ }^{1}$ \\ ${ }^{1}$ College of Animal Science, Jilin University, Changchun, 130062, P. R. China \\ ${ }^{2}$ College of Agriculture, Guangdong Ocean University, Zhanjiang, 523088, P. R. China \\ ${ }^{3}$ Institute of Animal Sciences, Chinese Academy of Agricultural Sciences, Beijing, 100193, P. R. China \\ ${ }^{4}$ Institute of Muscle Biology and Growth, Leibniz Institute for Farm Animal Biology (FBN), \\ Dummerstorf, 18196, Germany
}

Correspondence: Runjun Yang (yrj@jlu.edu.cn)

Received: 28 January 2019 - Revised: 22 February 2019 - Accepted: 25 February 2019 - Published: 29 March 2019

\begin{abstract}
Unlike specific expression in the skin of wild mice, the agouti signaling protein (ASIP) is expressed widely in the tissue of cattle, including adipose and muscle tissue. Hence, it has been suggested that ASIP plays a role in bovine fat metabolism. An inserted L1-BT element was recently identified upstream of the ASIP locus which led to an ectopic expression of ASIP mRNA in cattle. In this study, we detected the indel of the L1-BT element at g. $-14643 \mathrm{nt}$ and three SNPs in introns of the ASIP gene (g. $-568 \mathrm{~A}>\mathrm{G}, \mathrm{g} .-554 \mathrm{~A}>\mathrm{T}$, and g. $4805 \mathrm{~A}>\mathrm{T}$ ) in a Chinese Simmental steer population. The association analysis between variants of $A S I P$ and economic traits showed that the homozygous genotype of L1-BT element insertion, AA genotype of g. $-568 \mathrm{~A}>\mathrm{G}$, and AT genotype of g. $4805 \mathrm{~A}>\mathrm{T}$ were significantly correlated with carcass and fat-related traits, such as live weight and back fat thickness. Moreover, three haplotypes (H1: AT; H2: AA; H3: GT) were identified by linkage disequilibrium analysis and formed six combined genotypes. Results indicated that Chinese Simmental steers with an $\mathrm{H} 1 \mathrm{H} 2$ combined genotype had a higher measured value of fat-deposition-related traits $(p<0.05)$, including thickness of back fat and percentage of carcass fat coverage, but a lower content of linoleic acid and $\alpha$-linolenic acid $(p<0.05)$. Individuals of an $\mathrm{H} 3 \mathrm{H} 3$ combination had a lower marbling score, perirenal fat weight, and carcass weight $(p<0.05)$. This suggests that these three SNPs and two combined haplotypes might be molecular markers for beef cattle breeding selection.
\end{abstract}

1

\section{Introduction}

The Agouti signaling protein (ASIP) has been described as a secreted protein expressed mainly in the skin and regulated pigmentation in wild mice (Bultman et al., 1992; Voisey and van Daal, 2002). Mutations in ASIP, such as lethal yellow $\left(A^{\mathrm{y}}\right)$ and viable yellow $\left(A^{\mathrm{vy} / \mathrm{a}}\right)$, can lead to an overexpression in various tissues, including adipose and muscle tissue (Bultman et al., 1992; Morgan et al., 1999). The ectopic ASIP expression in mice caused not only yellow fur but also obesity (Klebig et al., 1995). Therefore, another biological function of $A S I P$ was suggested in the regulation of obesity in mice.

In human and farm animals, ASIP is ubiquitously expressed. ASIP mRNA could be detected in human adipose tissue, skin, heart, testis, ovary, liver, and kidney (Wilson et al., 1995). In pigs, the expression of ASIP could be found in liver and muscle (Zhao et al., 2015). Norris and Whan (2008) detected ASIP mRNA in the liver, kidney, skin, heart, and spleen of sheep. Several bovine studies had reported on ASIP mRNA expression in adipose tissue, $M$. longissimus, skin, heart, testis, ovary, and kidney (Girardot et al., 2005; Albrecht et al., 2012; Liu et al., 2018). Studies on ASIP in farm 
animals mainly focused on coat color (Kim et al., 2004; Norris and Whan, 2008; Mao et al., 2010; Li et al., 2014; Han et al., 2015; Zhang et al., 2017). Both Girardot et al. (2005) and Royo et al. (2005) found that there was no variant in coding exons of ASIP in different breeds of cattle with different coat color. A full-length element (L1-BT element; line 1) inserted at $5^{\prime}$ upstream of the ASIP gene was identified to give rise to an overexpression of ASIP in the skin of Normande cattle (Girardot et al., 2006). Girardot et al. (2006) concluded that the insertion of the L1-BT element may be the reason for the brindle coat color of the Normande cattle. The authors also presumed that the overexpression of ASIP caused by L1-BT element insertion may influence the meat production in cattle, as mice with ectopic expression of ASIP were obese. Liu et al. (2018) reported that in bulls of an $F_{2}$ generation (Charolais $\times$ Holstein) an extremely high level of ASIP mRNA was observed due to the L1-BT element insertion at $A S I P$ in 17 bulls, but no association with fat-related traits was found. However, there were significant correlations between the ASIP mRNA level of subcutaneous fat and traits related to fat deposition in bulls without an L1-BT element (Liu et al., 2018). Up to now, there is no research yet for L1-BT element insertion at the ASIP locus in Chinese cattle populations. Also, association analyses between single nucleotide polymorphism (SNP) of bovine ASIP and carcass traits and fatty acid composition in cattle have not been reported. Therefore, in this study we scanned for the L1-BT element and further SNPs at the ASIP locus in a population consisting of 363 Chinese Simmental steers. Here we focused on the traits related to fat deposition (e.g., marbling score, back fat thickness) and fatty acid composition, which can provide important information for meat production and quality in cattle. Carcass traits like liver weight and thigh meat thickness were also analyzed, as ASIP, a secreted protein, may circulate and act in the different tissues and parts of the body. The correlation between SNPs and traits was determined to illustrate the potential effect of ASIP in cattle, especially for meat production and meat quality.

\section{Materials and methods}

\subsection{Animals and sampling}

There were 363 Chinese Simmental steers involved in this study. Animals were randomly selected from 15 cattle farms in the Wulagai administrative district of Inner Mongolia in China. Steers were slaughtered at 28 months of age at the Inner Mongolia Baolongshan cattle farm (Tongliao, China). Carcass composition traits, meat quality traits, and fatty acid composition traits were measured at the Chinese Academy of Agricultural Sciences meat laboratory as described previously by Fang et al. (2017). Fatty acid content was extracted from M. longissimus and expressed as grams per $100 \mathrm{~g}$ fresh tissue. Blood samples ( $10 \mathrm{~mL}$ per animal) were collected from the jugular vein with anticoagulant (acid citrate dex- trose, ACD) and stored at $-80^{\circ} \mathrm{C}$ until further analysis. All animal experiments in this study abided strictly by the ordinance for the care and use of laboratory animals of the Jilin University Animal Care and Use Committee (permit number: SYXK (Ji) pzpx20181227083).

\subsection{ASIP variant detection and genotyping by sequencing}

DNA was extracted from leucocytes from whole blood samples (10 mL from each steer) using a TIANamp Blood DNA Kit (Tiangen, Beijing, China) and following the manufacturer's protocol. The purity and concentration of the genomic DNA were determined using a NanoDrop ND-2000 ultraviolet spectrophotometer (Thermo Fisher Scientific Inc., USA), and the quality was verified by agarose gel electrophoresis. Primers (Table 1) were designed using Primer $3 \mathrm{web}$ (Version 4.0.0, http://primer3.ut.ee/, last access: 10 December 2018) and synthesized by GENEWIZ, Inc. (Suzhou, China). Primer pairs of the ASIP L1-BT element and ASIP $5^{\prime}$ UTR (untranslated region) upstream (Table 1) were used for genotyping the indel of the L1-BT element upstream of $5^{\prime}$ UTR of ASIP. Both primer pairs shared the same forward primer which was located upstream of L1-BT element insertion. The reverse primer of the ASIP L1-BT element was designed at genomic $5^{\prime}$ junctions of the L1-BT element, whereas the location of the ASIP $5^{\prime}$ UTR upstream reverse primer is in a genomic region without L1-BT element insertion. Standard polymerase chain reaction (PCR) for both the ASIP L1-BT element and the ASIP 5' UTR upstream primer pairs was performed in each sample. All target sequences were amplified in a $30 \mu \mathrm{L}$ reaction volume including $15 \mu \mathrm{L}$ of $2 \times$ Green Taq PCR Mix (Vazyme, Nanjing, China), $0.2 \mu \mathrm{L}$ of forward and reverse primers $(10 \mu \mathrm{M}), 1 \mu \mathrm{L}$ of template DNA ( $50 \mathrm{ng} \mu \mathrm{L}^{-1}$ ), and $6.1 \mu \mathrm{L}$ of nuclease-free $\mathrm{H}_{2} \mathrm{O}$. The amplification started with an initial denaturation at $95^{\circ} \mathrm{C}$ for $5 \mathrm{~min}$, followed by 35 cycles with $95^{\circ} \mathrm{C}$ for $30 \mathrm{~s}$, a template-specific annealing temperature for $30 \mathrm{~s}, 72^{\circ} \mathrm{C}$ for $45 \mathrm{~s}$, and a final step with $72{ }^{\circ} \mathrm{C}$ for $10 \mathrm{~min}$. The annealing temperatures are provided in Table 1 . The PCR products of the ASIP L1-BT element and ASIP $5^{\prime}$ UTR upstream were run on $1 \%$ agarose gels and visualized under UV light (Alpha Innotech, USA) to genotype the L1-BT element indel. LL (homozygote of L1-BT element insertion) and GG (homozygote of the genomic sequence without L1-BT element insertion) genotypes were identified, respectively, when only the PCR product of the ASIP L1-BT element and the ASIP $5^{\prime}$ UTR upstream primer pairs was observed in one sample. The heterozygote of the L1-BT element indel (GL genotype) was determined when both PCR products of the ASIP L1BT element and ASIP $5^{\prime}$ UTR upstream were detected in one sample. Furthermore, PCR products were sent to GENEWIZ, Inc. (Suzhou, China), for sequencing. Sequences were analyzed by Chromas (Technelysium, Australia) to determine the SNP locations and genotypes. 
Table 1. Primer sequences.

\begin{tabular}{|c|c|c|c|c|}
\hline Primer name & Sequence $\left(5^{\prime} \rightarrow 3^{\prime}\right)$ & $\begin{array}{l}\text { Genbank acc. no. } \\
\text { position }\end{array}$ & $\begin{array}{l}\text { Amplicon } \\
\text { length (bp) }\end{array}$ & $\begin{array}{c}T_{\mathrm{a}} \\
\left({ }^{\circ} \mathrm{C}\right)\end{array}$ \\
\hline$A S I P$ L1-BT element ${ }^{1}$ & & NC_037340.1 ${ }^{2}$ & \multirow{3}{*}{420} & \multirow{3}{*}{62} \\
\hline For $^{3}$ & AAATCAACATCTCGGCTTGG & $1-20$ & & \\
\hline $\operatorname{Rev}^{4}$ & CTTTTCTGGGTGCCTGATGT & $420-398$ & & \\
\hline ASIP $5^{\prime}$ UTR upstream ${ }^{1}$ & & NC_037340.12 & \multirow{3}{*}{430} & \multirow{3}{*}{62} \\
\hline For & AAATCAACATCTCGGCTTGG & $1-20$ & & \\
\hline Rev & AAAAGGAAAGTGCGGAGGAG & $8841-8822$ & & \\
\hline ASIP_SNP1 & & NC_037340.1 ${ }^{2}$ & \multirow{3}{*}{996} & \multirow{3}{*}{58} \\
\hline For & TGAGTCACTTCAGTCGTGTCT & $22306-22326$ & & \\
\hline Rev & AGCAAGGTAGCCAGGAGGA & $23301-23263$ & & \\
\hline ASIP_SNP2 & & NC_037340.12 & \multirow{3}{*}{783} & \multirow{3}{*}{59} \\
\hline For & GGCTAGACTCCGAACCTACC & $27929-27945$ & & \\
\hline Rev & GCTAAGTAACCGCGTTTCCC & $28711-28692$ & & \\
\hline
\end{tabular}

\subsection{Statistical analysis}

The genotype frequency and allelic frequency of each SNP were calculated according to genotyping results. The polymorphism information component (PIC) was determined by Botstein's methods (Botstein et al., 1980). The HardyWeinberg equilibrium of the polymorphisms was tested with the chi-squared $\left(\chi^{2}\right)$ test. Associations between ASIP gene polymorphisms and economic traits of beef cattle were analyzed by two-way analysis of variance (ANOVA) using SPSS 13.0 for Windows. The fixed model was

$Y_{i j k}=u+y s_{i}+m_{j}+e_{i j k}$,

where $Y_{i j k}$ is the observed value of the $k$ th individual from the Simmental breed of genotype $j$ in the $i$ th-year season, $u$ is the lowest square mean of the observed values, $y s_{i}$ is the effective value of the $i$ th-year season, $m_{j}$ is the effective value of genotype $j$, and $e_{i j k}$ is the random residual effect corresponding to the observed value. For SNPs that correlated with the carcass and fat-related traits, the haplotype test and linkage disequilibrium (LD) were performed and measured by $D^{\prime}$ and $r^{2}$ with the HaploView software (Daly Lab at the Broad Institute Cambridge, USA, ver. 3.32) (Barrett et al., 2005).

\section{Results}

\subsection{Screening of SNP loci of the ASIP gene in Chinese Simmental population}

Sequencing results showed that all PCR products are specific and correct as designed. The indel of the L1-BT element upstream of $5^{\prime}$ UTR of ASIP (at g. $-14643 \mathrm{nt}$ ) was detected by electrophoresis (Fig. 1a). Three SNPs, including g. $-568 \mathrm{~A}>\mathrm{G}$ (located in intron1), g. $-554 \mathrm{~A}>\mathrm{T}$ (located in intron1), and g. 4805A $>\mathrm{T}$ (located in intron3), were identified in 363 Chinese Simmental steers and genotyped according to sequencing results (Fig. 1a).

\subsection{Genetic diversity of SNPs in the ASIP gene in Chinese Simmental population}

Values of genotypic frequencies, allelic frequencies, PIC, Ho (gene homozygosity), and $\mathrm{He}$ (gene heterozygosity) were calculated to illustrate the genetic diversity of ASIP in Chinese Simmental steers (Table 2). The percentage of Ho in three SNPs was higher than that of He. The PIC value of g. $-568 \mathrm{~A}>\mathrm{G}, 0.29$, indicated an intermediate polymorphism frequency of SNP $(0.25<$ PIC value $<0.5$, intermediate polymorphism). g. $-554 \mathrm{~A}>\mathrm{T}$ with a $0.12 \mathrm{PIC}$ value showed a low polymorphism frequency (PIC value $<0.25$, low polymorphism). g. 4805A $>\mathrm{T}$ had a high polymorphism frequency with a 0.5 PIC value (PIC value $>0.5$, high polymorphism). All three SNPs fit the Hardy-Weinberg equilibrium in the population $(P>0.05)$.

\subsection{Correlation analyses of ASIP polymorphisms with carcass and fat deposition traits}

The associations between variants and traits are presented in Table 3. Steers heterozygous of the L1-BT element indel had a heavier liver weight $(P<0.05)$. Compared to other two genotypes, individuals carrying a homozygous insertion of the L1-BT element possessed a lower value regarding the weight of the kidneys $(P<0.05)$ and perirenal fat $(P<0.01)$, in the thickness of waist meat $(P<0.05)$ and back fat $(P<0.01)$, and in the percentage of carcass fat coverage $(P<0.01)$. For g. $-568 \mathrm{nt}$, steers of the AA geno- 
(a)

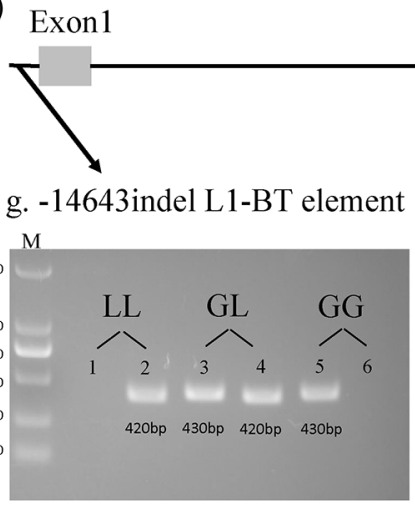

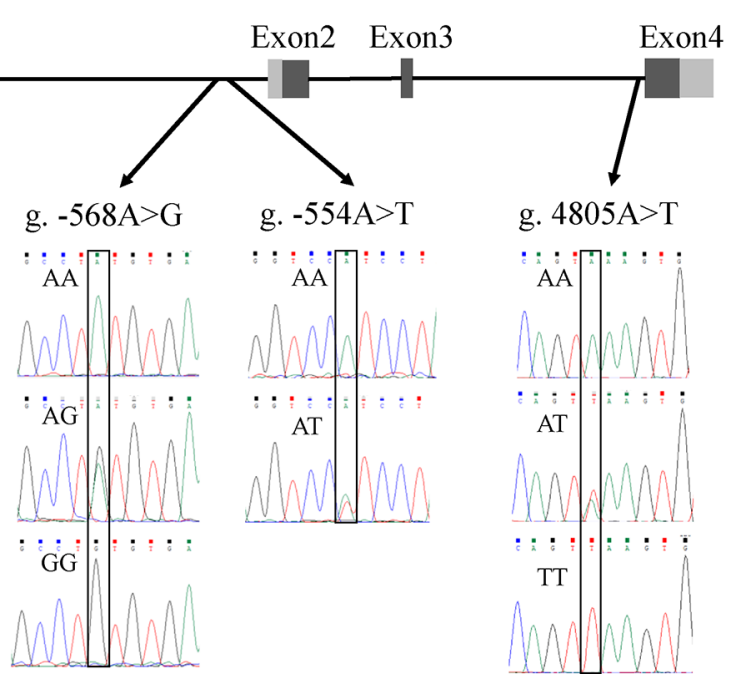

(b)

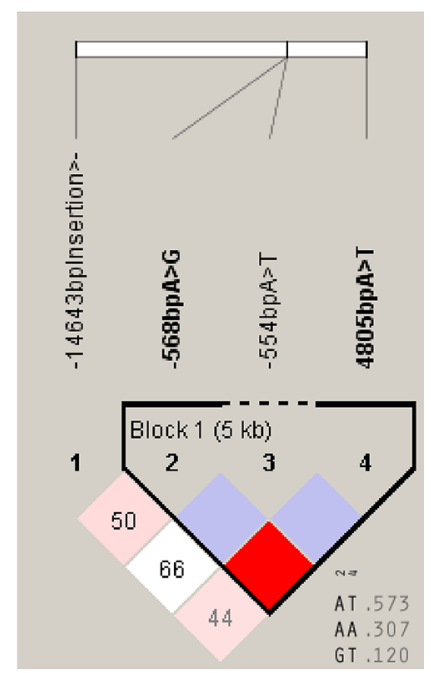

Figure 1. SNP detection at the ASIP locus in Chinese Simmental steers and linkage and haplotype analysis. (a) Non-coding (gray) and coding (black) exons are presented as a box. For the g. -14643 indel L1-BT element, PCR products in lane 1 and 2, lane 3 and 4 , and lane 5 and 6 were amplified from templates of three different steers. The LL genotype (homozygote of L1-BT element insertion) was presented when only the PCR product of the ASIP L1-BT element primer pair was detected in one sample. The GL genotype (heterozygote of L1-BT element insertion) was determined when PCR products were amplified by both primer pairs of ASIP 5' UTR upstream and the ASIP L1-BT element in one sample. The GG genotype (no L1-BT element inserted) was identified when only the PCR product of the ASIP $5^{\prime}$ UTR upstream primer pair was detected in one sample. Lanes: M - size marker; 1, 3,5 - specific PCR products of ASIP $5^{\prime}$ UTR upstream primer pair at $430 \mathrm{bp}$ are genomic sequences with no L1-BT element; 2, 4, 6 - PCR products (420 bp) containing the partial sequence of the L1-BT element. (b) Box with red color presents strong linkage between g. $-568 \mathrm{~A}>\mathrm{G}$ and g. 4805A $>$ T. Three haplotypes are shown with haplotype frequency.

Table 2. Genetic diversity of the ASIP gene.

\begin{tabular}{|c|c|c|c|c|c|c|c|c|c|c|}
\hline \multirow{2}{*}{$\begin{array}{l}\text { Variants* }^{*} \\
\text { L1-BT element indel }\end{array}$} & \multirow{2}{*}{$\begin{array}{l}\text { Location } \\
\text { Upstream }\end{array}$} & \multicolumn{2}{|c|}{$\begin{array}{c}\text { Allele } \\
\text { frequency }\end{array}$} & \multicolumn{3}{|c|}{ Genotype frequency } & \multirow{2}{*}{$\frac{\text { PIC }^{\mathrm{a}}}{-}$} & \multirow{2}{*}{$\frac{\mathrm{Ho}^{\mathrm{b}}}{-}$} & \multirow{2}{*}{$\frac{\mathrm{He}^{\mathrm{c}}}{-}$} & \multirow{2}{*}{$\begin{array}{c}\text { Variant ID } \\
-\end{array}$} \\
\hline & & $\begin{array}{l}\mathrm{L} \\
0.146\end{array}$ & $\begin{array}{l}\mathrm{G} \\
0.854\end{array}$ & $\begin{array}{l}\text { LL } \\
0.006\end{array}$ & $\begin{array}{l}\text { GL } \\
0.281\end{array}$ & $\begin{array}{l}\text { GG } \\
0.713\end{array}$ & & & & \\
\hline g. $-568 \mathrm{~A}>\mathrm{G}$ & Intron1 & $\begin{array}{l}\text { A } \\
0.888\end{array}$ & $\begin{array}{l}\mathrm{G} \\
0.112\end{array}$ & $\begin{array}{l}\text { AA } \\
0.787\end{array}$ & $\begin{array}{l}\text { AG } \\
0.201\end{array}$ & $\begin{array}{l}\text { CC } \\
0.012\end{array}$ & 0.29 & 0.80 & 0.20 & rs379766904 \\
\hline g. $-554 \mathrm{~A}>\mathrm{T}$ & Intron1 & $\begin{array}{l}\text { A } \\
0.965\end{array}$ & $\begin{array}{l}\mathrm{T} \\
0.035\end{array}$ & $\begin{array}{l}\text { AA } \\
0.930\end{array}$ & $\begin{array}{l}\text { AT } \\
0.070\end{array}$ & $\begin{array}{l}\text { TT } \\
0.00\end{array}$ & 0.12 & 0.93 & 0.07 & rs382441624 \\
\hline g. $4805 \mathrm{~A}>\mathrm{T}$ & Intron3 & $\begin{array}{l}\text { A } \\
0.306\end{array}$ & $\begin{array}{l}\mathrm{T} \\
0.694\end{array}$ & $\begin{array}{l}\text { AA } \\
0.110\end{array}$ & $\begin{array}{l}\text { TA } \\
0.392\end{array}$ & $\begin{array}{l}\text { TT } \\
0.498\end{array}$ & 0.50 & 0.61 & 0.39 & rs208055105 \\
\hline
\end{tabular}

${ }^{*}$ The A base of the start codon ATG was regarded as the first base. ${ }^{a}$ Polymorphism information component. ${ }^{\mathrm{b}}$ Ho: gene homozygosity. ${ }^{\mathrm{c}}$ He: gene heterozygosity.

d LL: homozygote of L1-BT element insertion; GL: heterozygote of L1-BT element insertion; GG: no L1-BT element inserted.

type had a higher live weight $(P<0.05)$ and carcass $\mathrm{pH}$ values $(P<0.05)$ than GG genotype individuals. Moreover, the marbling score of AA and AT genotype steers was higher than in GG steers $(P<0.05)$. At g. $4805 \mathrm{nt}$ of $A S I P$, a heavier liver weight $(P<0.01)$, carcass weight $(P<0.05)$, and higher dressing percentage $(P<0.05)$ were observed in individuals with the AT genotype compared with the TT genotype. Steers of the AT genotype had thicker back fat and a higher carcass fat coverage rate. There was no significant association between g. $-554 \mathrm{~A}>\mathrm{T}$ and the investigated traits. In fatty acid composition, there was no statistical difference among genotypes of each SNP in either saturated fatty acid content or in polyunsaturated fatty acid content (data not shown).

\subsection{Haplotype analysis and association analyses of dominant haplotypes with carcass traits and fatty acid composition}

The linkage analysis of three investigated SNPs in ASIP is shown in Fig. 1b. Linkage was observed only between SNPs at g. $-568 \mathrm{nt}$ and g. $4805 \mathrm{nt}\left(D^{\prime}=1\right.$; LOD (logarithm of the 


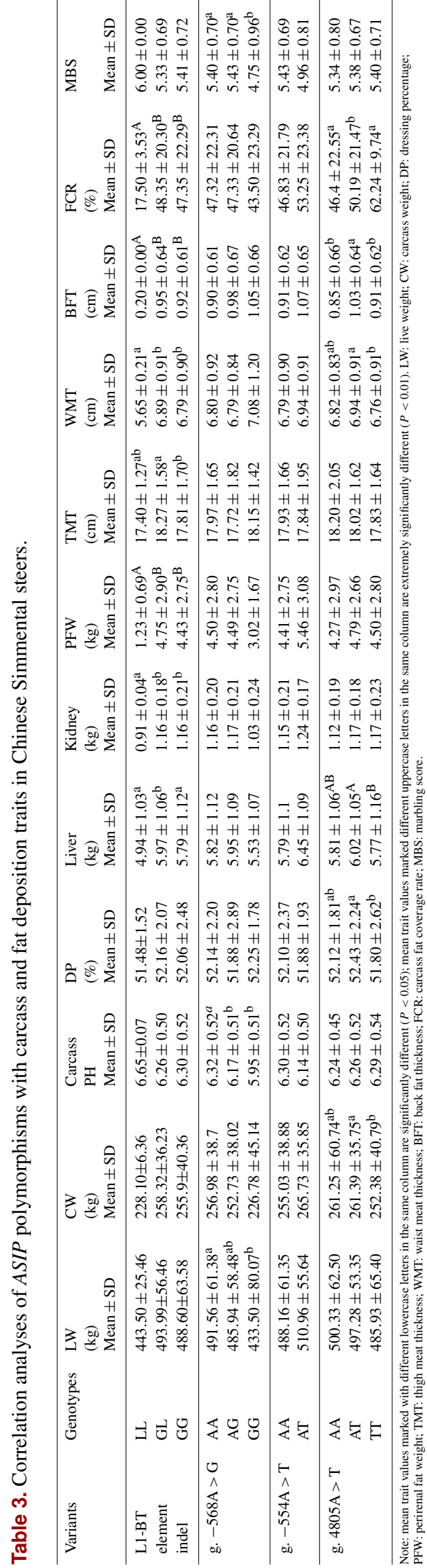

odds $\left.)=6.7 ; r^{2}=0.06\right)$. Three haplotypes $(\mathrm{H} 1: \mathrm{AT} ; \mathrm{H} 2$ : AA; H3: GT) were detected and generated six haplotype combinations. The combined haplotypes $\mathrm{H} 1 \mathrm{H} 2$ and $\mathrm{H} 3 \mathrm{H} 3$ had the highest and lowest genotypic frequency: $33.5 \%$ and $1.3 \%$, respectively. The correlation analysis (Table 4) indicated that steers with an $\mathrm{H} 1 \mathrm{H} 2$ genotype had higher live weight, carcass weight, and perirenal fat than those with an $\mathrm{H} 3 \mathrm{H} 3$ haplotype combination $(P<0.05)$. The thickness of back fat was significantly greater in steers with an $\mathrm{H} 1 \mathrm{H} 2$ combination compared to that with $\mathrm{H} 1 \mathrm{H} 1(P<0.01)$ and $\mathrm{H} 2 \mathrm{H} 2$ $(P<0.05)$. A higher carcass fat coverage rate could be observed in $\mathrm{H} 1 \mathrm{H} 2$ genotype individuals compared to $\mathrm{H} 1 \mathrm{H} 1$ $(P<0.01)$ and $\mathrm{H} 2 \mathrm{H} 2$ steers $(P<0.05)$. The carcass $\mathrm{pH}$ value of $\mathrm{H} 1 \mathrm{H} 2$ steers was significantly higher than that of H1H3 $(P<0.05)$ and H3H3 $(P<0.05)$ individuals. Moreover, individuals with an $\mathrm{H} 3 \mathrm{H} 3$ haplotype combination got a lower marbling score than steers of $\mathrm{H} 1 \mathrm{H} 1, \mathrm{H} 1 \mathrm{H} 2$, or $\mathrm{H} 1 \mathrm{H} 3$ $(P<0.05)$.

The association between dominant haplotypes and the content of either saturated fatty acids or polyunsaturated fatty acids was analyzed. Results indicated that the content of linoleic acid in longissimus dorsi of $\mathrm{H} 1 \mathrm{H} 2$ steers was lower than that in $\mathrm{H} 1 \mathrm{H} 3$ steers $(P<0.05)$ (Table 5). Moreover, a lower content of $\alpha$-linolenic acid was observed in individuals with an $\mathrm{H} 1 \mathrm{H} 2$ genotype compared to that in $\mathrm{H} 2 \mathrm{H} 2$ steers $(P<0.05)$ (Table 5)

\section{Discussion}

In mice, there are five dominant mutations causing ectopic expression of ASIP (Voisey and van Daal, 2002). Insertions of different sizes upstream of first coding exon are the cause for intracisternal A-particle yellow ( $A^{\text {iapy }}$ ), intermediate yellow $\left(A^{\mathrm{iy}}\right)$, sienna yellow $\left(A^{\mathrm{sy}}\right)$, and viable yellow $\left(A^{\mathrm{vy}}\right) \mathrm{mu}-$ tation (Duhl et al., 1994; Michaud et al., 1994b; Siracusa et al., 1995). In the case of the $A^{\mathrm{y}}$ mutation, ASIP is controlled by the $R A L Y$ promoter due to the deletion at both the $R A L Y$ and the ASIP locus. It happened only in the $A^{\mathrm{y}}$ mutation that the homozygosity of $A^{\mathrm{y}}$ resulted in embryonic lethality (Michaud et al., 1994a). Long interspersed nuclear elements (lines; L1s) known as autonomously mobile DNA sequences belong to autonomous retrotransposon lacking long terminal repeats (LTRs) (Kazazian and Moran, 1998). This is one of the most abundant retrotransposon in eukaryotes (Kazazian and Moran, 1998; Walsh et al., 2013). Girardot et al. (2005) observed L1-BT element insertion upstream of ASIP in bulls. The insertion of the L1-BT element formed a new non-coding exon which resulted in an overexpression of ASIP (Girardot et al., 2005). Both the homozygote and heterozygote of the L1-BT element indel were detected in bulls of the Montbéliarde breed (Girardot et al., 2006). Albrecht et al. (2012) found heterozygote insertion of this element, which gave rise to an ectopic expression of ASIP in different tissues of Japanese Black and Charolais cattle. In 


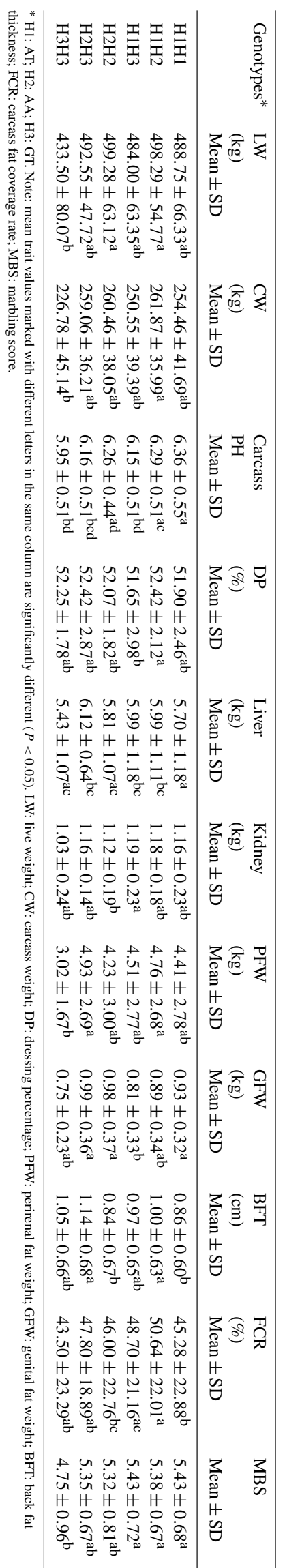

our study, three genotypes of the L1-BT element indel were also detected. It is obvious that homozygosity of L1-BT element insertion is not a lethal factor in cattle. Liu et al. (2018) reported that steers with a heterozygote of the L1-BT element indel had an extremely high ASIP mRNA level in various tissues, but it was not associated with any traits related to fat deposition. In the current study, there was no significant difference between GL and GG genotype Chinese Simmental steers in fat-related traits. However, steers with the LL genotype had lower perirenal fat weight, thinner back fat, and less carcass fat coverage percentage compared with other genotypes $(P<0.05)$. According to previous knowledge that $A S I P$ is highly expressed in L1-BT-inserted bulls (Girardot et al., 2006), it can be presumed that in this Chinese Simmental population overexpression of ASIP in steers with the LL genotype showed a negative association with traits related to fat deposition. In a previous study, we found that a heterozygous insertion of L1-BT led to an ectopic expression of ASIP mRNA but not protein (Liu et al., 2018). Hence, further experiments should focus on the expression pattern and effect of ASIP in cattle with the LL genotype.

In this study, we detected the L1-BT element indel and three SNPs at the bovine ASIP locus. Among them, indel of the L1-BT element at g. $-14643 \mathrm{nt}, \mathrm{g}$. $-568 \mathrm{~A}>\mathrm{G}$, and g. $4805 \mathrm{~A}>\mathrm{T}$ showed significant associations with traits related to fat deposition (e.g., back fat thickness and carcass fat coverage rate) in 363 Chinese Simmental steers. The mutations of g. $-568 \mathrm{~A}>\mathrm{G}$ and g. $4805 \mathrm{~A}>\mathrm{T}$ occurred in introns and did not alter the amino acid sequence of ASIP. However, mutations in introns may also influence the expression and function of a gene by aberrant splicing (Komar, 2007; Shastry, 2009). Coding exons were scanned for SNPs in this study, but no variant of ASIP could be found (data not shown). Likewise, Girardot et al. (2005) and Royo et al. (2005) did not find any SNP of bovine ASIP in coding exons. This suggested that the coding region of bovine ASIP is highly conserved. The analysis of haplotypes is an important component of genetic association analysis. A haplotype consists of a group of linked SNP markers, and it may increase the coverage value of genotype over single SNP analysis (Stram, 2017). The association analysis between haplotype combinations and traits of Chinese Simmental steers indicated that the $\mathrm{H} 1 \mathrm{H} 2$ genotype was positively correlated to carcass and meat quality traits, e.g., with a higher carcass weight and thicker back fat. But the $\mathrm{H} 3 \mathrm{H} 3$ genotype had a negative association with fat-related traits such as a lower marbling score and perirenal fat weight. Moreover, linoleic acid and $\alpha$-linolenic acid are essential fatty acids which can only be obtained from the diet (Spector and Kim, 2015). Our results showed that H1H2 steer individuals had a lower content of linoleic acid and $\alpha$ linolenic acid than the $\mathrm{H} 1 \mathrm{H} 3$ and $\mathrm{H} 2 \mathrm{H} 2$ genotypes, respectively. These results may illustrate that Chinese Simmental steers with an $\mathrm{H} 1 \mathrm{H} 2$ genotype may have more fat deposition in the body but less essential fatty acids, e.g., linoleic acid and $\alpha$-linolenic acid, in longissimus dorsi. 
Table 5. The effect of five haplotype combinations on fatty acid components in Chinese Simmental steers.

\begin{tabular}{|c|c|c|c|c|c|}
\hline \multirow[t]{2}{*}{ Fatty acid content $\left({\left.\mathrm{g} 100 \mathrm{~g}^{-1}\right)}^{-1}\right.$} & \multicolumn{5}{|c|}{ Genotype* } \\
\hline & $\mathrm{H} 1 \mathrm{H} 1$ & $\mathrm{H} 1 \mathrm{H} 2$ & $\mathrm{H} 1 \mathrm{H} 3$ & $\mathrm{H} 2 \mathrm{H} 2$ & $\mathrm{H} 2 \mathrm{H} 3$ \\
\hline Myristic acid (c14:0) & $0.0220 \pm 0.018$ & $0.0223 \pm 0.020$ & $0.0171 \pm 0.007$ & $0.0187 \pm 0.012$ & $0.0128 \pm 0.008$ \\
\hline Nutmeg oleic acid (c14:1) & $0.0023 \pm 0.005$ & $0.0031 \pm 0.007$ & $0.0019 \pm 0.003$ & $0.0012 \pm 0.003$ & $0.0025 \pm 0.003$ \\
\hline Hexadecanoic acid (c16:0) & $0.2701 \pm 0.183$ & $0.2809 \pm 0.257$ & $0.2279 \pm 0.090$ & $0.2484 \pm 0.133$ & $0.1979 \pm 0.082$ \\
\hline Palmitoleic acid (c16:1) & $0.0282 \pm 0.020$ & $0.0329 \pm 0.050$ & $0.0239 \pm 0.009$ & $0.0216 \pm 0.011$ & $0.0261 \pm 0.012$ \\
\hline Margaric acid (c17:0) & $0.0120 \pm 0.007$ & $0.0114 \pm 0.008$ & $0.0108 \pm 0.005$ & $0.0108 \pm 0.007$ & $0.0072 \pm 0.004$ \\
\hline Heptadecanoic acid (c17:1) & $0.0052 \pm 0.006$ & $0.0059 \pm 0.010$ & $0.0046 \pm 0.005$ & $0.0046 \pm 0.005$ & $0.0052 \pm 0.005$ \\
\hline Stearic acid (c18:0) & $0.1995 \pm 0.123$ & $0.1879 \pm 0.118$ & $0.1860 \pm 0.083$ & $0.1839 \pm 0.107$ & $0.1308 \pm 0.038$ \\
\hline Oleic acid $(\mathrm{C} 18: 1 \mathrm{n} 9 \mathrm{c})$ & $0.3619 \pm 0.237$ & $0.4393 \pm 0.613$ & $0.3087 \pm 0.136$ & $0.3338 \pm 0.163$ & $0.2877 \pm 0.126$ \\
\hline Linoleic acid (C18:2n6c) & $0.1070 \pm 0.040^{\mathrm{ab}}$ & $0.0927 \pm 0.025^{\mathrm{a}}$ & $0.1172 \pm 0.051^{\mathrm{b}}$ & $0.1087 \pm 0.033^{\mathrm{ab}}$ & $0.0888 \pm 0.002^{\mathrm{ab}}$ \\
\hline$\alpha$-Linolenic acid (ac18:3n3) & $0.0068 \pm 0.009^{\mathrm{ab}}$ & $0.0048 \pm 0.005^{\mathrm{a}}$ & $0.0069 \pm 0.008^{\mathrm{ab}}$ & $0.0099 \pm 0.007^{\mathrm{b}}$ & $0.0039 \pm 0.004^{\mathrm{ab}}$ \\
\hline Arachidic acid (c20:0) & $0.0015 \pm 0.005$ & $0.0004 \pm 0.001$ & $0.0004 \pm 0.001$ & $0.0003 \pm 0.001$ & $0.0008 \pm 0.001$ \\
\hline Eicosenoic an acid (c20:1) & $0.0005 \pm 0.002$ & $0.0007 \pm 0.004$ & $0.0003 \pm 0.001$ & $0.0002 \pm 0.001$ & $0.0007 \pm 0.001$ \\
\hline Dohono-c-linolenic acid (c20:3n6) & $0.0101 \pm 0.003$ & $0.0099 \pm 0.003$ & $0.0106 \pm 0.002$ & $0.0097 \pm 0.001$ & $0.0100 \pm 0.002$ \\
\hline Arachidonic acid (c20:4n6) & $0.0525 \pm 0.014$ & $0.0488 \pm 0.015$ & $0.0506 \pm 0.011$ & $0.0470 \pm 0.013$ & $0.0483 \pm 0.009$ \\
\hline
\end{tabular}

${ }^{*} \mathrm{H} 1$ : AT; H2: AA; H3: GT. Note: data were presented as mean \pm SD. Mean trait values marked with different letters in the same row are significantly different $(P<0.05)$.

\section{Conclusion}

In summary, both polymorphisms and haplotype analysis of ASIP showed significant correlations with fat-related traits in Chinese Simmental steers. This suggests that ASIP is involved in fat deposition at different stages of the growth and fattening of beef cattle, such as intramuscular fat, back fat, and perirenal fat deposition. The haplotype combinations of $\mathrm{H} 1 \mathrm{H} 2$ and $\mathrm{H} 3 \mathrm{H} 3$ may be molecular markers for traits related to fat deposition and meat quality (e.g., fatty acid composition). However, further studies are necessary to unravel the mechanism of how the ASIP gene affects meat production and quality in cattle.

Data availability. The data sets are available upon request from the corresponding author.

Author contributions. YL and XF contributed equally to this work. YL performed parts of experiments and drafted the manuscript. XF designed and performed parts of the experiments and revised the manuscript. ZZ designed part of the experiments and revised the manuscript. JL collected and provided data. EA, LS, and SM supervised parts of the work and revised the manuscript. YR analyzed the data and supervised the work, and revised the manuscript. All authors approved the final version of the manuscript.

Competing interests. One of the authors, Steffen Maak, is chief editor of Archives Animal Breeding but was neither involved in editorial decisions nor in the peer review process regarding this article.
Acknowledgements. This work was supported by the $\mathrm{Na}$ tional Natural Science Foundation of China (no. 31672389 and no. 31772562), the National Major Special Project on New Varieties Cultivation for Transgenic Organisms (2016ZX08009003-006), the Jilin Scientific and Technological Development Program (no. 20170519014JH and no. 20180101275JC), and the Jilin province industrial technology research and development program (2016C032).

Edited by: Antke-Elsabe Freifrau von Tiele-Winckler Reviewed by: two anonymous referees

\section{References}

Albrecht, E., Komolka, K., Kuzinski, J., and Maak, S.: Agouti revisited: transcript quantification of the ASIP gene in bovine tissues related to protein expression and localization, PloS One, 7, e35282, https://doi.org/10.1371/journal.pone.0035282, 2012.

Barrett, J. C., Fry, B., Maller, J., and Daly, M. J.: Haploview: analysis and visualization of LD and haplotype maps, Bioinforma. Oxf. Engl., 21, 263-265, https://doi.org/10.1093/bioinformatics/bth457, 2005.

Botstein, D., White, R. L., Skolnick, M., and Davis, R. W.: Construction of a genetic linkage map in man using restriction fragment length polymorphisms, Am. J. Hum. Genet., 32, 314-331, 1980.

Bultman, S. J., Michaud, E. J., and Woychik, R. P.: Molecular characterization of the mouse agouti locus, Cell, 71, 1195-1204, 1992.

Duhl, D. M., Vrieling, H., Miller, K. A., Wolff, G. L., and Barsh, G. S.: Neomorphic agouti mutations in obese yellow mice, Nat. Genet., 8, 59-65, https://doi.org/10.1038/ng0994-59, 1994.

Fang, X., Zhao, Z., Jiang, P., Yu, H., Xiao, H., and Yang, R.: Identification of the bovine HSL gene expression profiles and its association with fatty acid composi- 
tion and fat deposition traits, Meat Sci., 131, 107-118, https://doi.org/10.1016/j.meatsci.2017.05.003, 2017.

Girardot, M., Martin, J., Guibert, S., Leveziel, H., Julien, R., and Oulmouden, A.: Widespread expression of the bovine Agouti gene results from at least three alternative promoters, Pigment Cell Res., 18, 34-41, https://doi.org/10.1111/j.16000749.2004.00195.x, 2005.

Girardot, M., Guibert, S., Laforet, M.-P., Gallard, Y., Larroque, H., and Oulmouden, A.: The insertion of a full-length Bos taurus LINE element is responsible for a transcriptional deregulation of the Normande Agouti gene, Pigment Cell Res., 19, 346-355, https://doi.org/10.1111/j.1600-0749.2006.00312.x, 2006.

Han, J. L., Yang, M., Yue, Y. J., Guo, T. T., Liu, J. B., Niu, C. E., and Yang, B. H.: Analysis of agouti signaling protein (ASIP) gene polymorphisms and association with coat color in Tibetan sheep (Ovis aries), Genet. Mol. Res. GMR, 14, 1200-1209, https://doi.org/10.4238/2015.February.6.22, 2015.

Kazazian, H. H. and Moran, J. V.: The impact of L1 retrotransposons on the human genome, Nat. Genet., 19, 19-24, https://doi.org/10.1038/ng0598-19, 1998.

Kim, T. H., Choi, B. H., and Beever, J. E.: Polymorphism in the porcine agouti signalling protein (ASIP) gene, Anim. Genet., 35, 418-420, https://doi.org/10.1111/j.1365-2052.2004.01179.x, 2004.

Klebig, M. L., Wilkinson, J. E., Geisler, J. G., and Woychik, R. P.: Ectopic expression of the agouti gene in transgenic mice causes obesity, features of type II diabetes, and yellow fur, P. Natl. Acad. Sci. USA, 92, 4728-4732, https://doi.org/10.1073/pnas.92.11.4728, 1995.

Komar, A. A.: Silent SNPs: impact on gene function and phenotype, Pharmacogenomics, 8, 1075-1080, https://doi.org/10.2217/14622416.8.8.1075, 2007.

Li, M.-H., Tiirikka, T., and Kantanen, J.: A genome-wide scan study identifies a single nucleotide substitution in ASIP associated with white versus non-white coat-colour variation in sheep (Ovis aries), Heredity, 112, 122-131, https://doi.org/10.1038/hdy.2013.83, 2014.

Liu, Y., Albrecht, E., Schering, L., Kuehn, C., Yang, R., Zhao, Z., and Maak, S.: Agouti Signaling Protein and Its Receptors as Potential Molecular Markers for Intramuscular and Body Fat Deposition in Cattle, Front. Physiol., 9, 172, https://doi.org/10.3389/fphys.2018.00172, 2018.

Mao, H., Ren, J., Ding, N., Xiao, S., and Huang, L.: Genetic variation within coat color genes of MC1R and ASIP in Chinese brownish red Tibetan pigs, Anim. Sci. J. Nihon Chikusan Gakkaiho, 81, 630-634, https://doi.org/10.1111/j.17400929.2010.00789.x, 2010.

Michaud, E. J., Bultman, S. J., Klebig, M. L., van Vugt, M. J., Stubbs, L. J., Russell, L. B., and Woychik, R. P.: A molecular model for the genetic and phenotypic characteristics of the mouse lethal yellow (Ay) mutation, P. Natl. Acad. Sci. USA, 91, 25622566, https://doi.org/10.1073/pnas.91.7.2562, 1994a.
Michaud, E. J., van Vugt, M. J., Bultman, S. J., Sweet, H. O., Davisson, M. T., and Woychik, R. P.: Differential expression of a new dominant agouti allele (Aiapy) is correlated with methylation state and is influenced by parental lineage, Genes Dev., 8, 1463 1472, https://doi.org/10.1101/gad.8.12.1463, 1994b.

Morgan, H. D., Sutherland, H. G. E., Martin, D. I. K., and Whitelaw, E.: Epigenetic inheritance at the agouti locus in the mouse, Nat. Genet., 23, 314-318, https://doi.org/10.1038/15490, 1999.

Norris, B. J. and Whan, V. A.: A gene duplication affecting expression of the ovine ASIP gene is responsible for white and black sheep, Genome Res., 18, 1282-1293, https://doi.org/10.1101/gr.072090.107, 2008.

Royo, L. J., Álvarez, I., Fernández, I., Arranz, J. J., Gómez, E., and Goyache, F.: The coding sequence of the ASIP gene is identical in nine wild-type coloured cattle breeds, J. Anim. Breed. Genet., 122, 357-360, https://doi.org/10.1111/j.14390388.2005.00541.x, 2005.

Shastry, B. S.: SNPs: impact on gene function and phenotype, Meth. Mol. Biol. Clifton NJ, 578, 3-22, https://doi.org/10.1007/978-160327-411-1_1, 2009.

Siracusa, L. D., Washburn, L. L., Swing, D. A., Argeson, A. C., Jenkins, N. A., and Copeland, N. G.: Hypervariable yellow (Ahvy), a new murine agouti mutation: Ahvy displays the largest variation in coat color phenotypes of all known agouti alleles, J. Hered., 86, 121-128, https://doi.org/10.1093/oxfordjournals.jhered.a111541, 1995.

Spector, A. A. and Kim, H.-Y.: Discovery of essential fatty acids, J. Lipid Res., 56, 11-21, https://doi.org/10.1194/jlr.R055095, 2015.

Stram, D. O.: Multi-SNP Haplotype Analysis Methods for Association Analysis, Meth. Mol. Biol. Clifton NJ, 1666, 485-504, https://doi.org/10.1007/978-1-4939-7274-6_24, 2017.

Voisey, J. and van Daal, A.: Agouti: from mouse to man, from skin to fat, Pigment Cell Res., 15, 10-18, https://doi.org/10.1034/j.1600-0749.2002.00039.x, 2002.

Walsh, A. M., Kortschak, R. D., Gardner, M. G., Bertozzi, T., and Adelson, D. L.: Widespread horizontal transfer of retrotransposons, P. Natl. Acad. Sci. USA, 110, 1012-1016, https://doi.org/10.1073/pnas.1205856110, 2013.

Wilson, B. D., Ollmann, M. M., Kang, L., Stoffel, M., Bell, G. I., and Barsh, G. S.: Structure and function of ASP, the human homolog of the mouse agouti gene, Hum. Mol. Genet., 4, 223-230, https://doi.org/10.1093/hmg/4.2.223, 1995.

Zhang, X., Li, W., Liu, C., Peng, X., Lin, J., He, S., Li, X., Han, B., Zhang, N., Wu, Y., Chen, L., Wang, L., MaYila, N., Huang, J., and Liu, M.: Alteration of sheep coat color pattern by disruption of ASIP gene via CRISPR Cas9, Sci. Rep., 7, 8149, https://doi.org/10.1038/s41598-017-08636-0, 2017.

Zhao, H., Li, K., Tang, J.-Y., Zhou, J.-C., Wang, K.-N., Xia, X.-J., and Lei, X. G.: Expression of Selenoprotein Genes Is Affected by Obesity of Pigs Fed a High-Fat Diet, J. Nutr., 145, 1394-1401, https://doi.org/10.3945/jn.115.211318, 2015. 